\title{
Scientific events, power relationships and practices of researchers
}

\author{
Os eventos científicos, as relações de poder \\ e as práticas dos pesquisadores
}

\author{
Murilo Artur Araújo da SILVEIRA' \\ Leilah Santiago BUFREM' \\ Sônia Elisa CAREGNATO²
}

\begin{abstract}
The aim of the article is to discuss theoretically the power relationships that materialize themselves in practices carried out by researchers in scientific forums, based on the Pierre Bourdieu's concepts of production, reproduction and distinction in the scientific universe. We assume that events are instances of reproduction of scientific activity in which power relationships are intend to maintain and perpetuate positions attained. We conducted a literature review on the nature, size, functions and organization of scientific forums as instruments that enable the production and dissemination of knowledge. We point out that ideological components are determinant of unequal relationships between the dominant and dominated in the scientific forums, while ratifying the dynamics of social reproduction. We discuss how power relationships develop in the acts and discourses that constitute researchers' practices during scientific forums, particularly the scenic resources of actions and the scientific effects of representations of domination.
\end{abstract}

Keywords: Power relationships. Scientific communication. Scientific forums. Scientific practices.

\section{Resumo}

Discute teoricamente as relações de poder que se materializam nas práticas realizadas pelos pesquisadores nos eventos científicos, com base nos postulados de Pierre Bourdieu sobre produção, reprodução e distinção no universo científico. Parte da premissa de que os eventos são instâncias de reprodução da atividade científica em que as relações de poder se manifestam para manutenção e perpetuação das posições alcançadas. Revisa a literatura sobre a natureza, as dimensões, funções e formas de organização dos eventos científicos enquanto instrumentos que viabilizam a produção e disseminação do conhecimento. Aponta como os componentes ideológicos são determinantes nas relações desiguais entre dominantes e dominados nos eventos científicos, ao mesmo tempo em que ratificam a dinâmica de reprodução social. Evidencia como se processam as relações de poder nos atos e discursos que constituem as práticas dos pesquisadores nos eventos, com destaque para os recursos cênicos das ações e os efeitos científicos das representações de dominação.

Palavras-chave: Relações de poder. Comunicação científica. Eventos científicos. Práticas científicas.

\section{Introduction}

During their development, scientific practices seek to produce, communicate and use knowledge while scientists are responsible for their implementation, maintenance and institutionalization. These practices are developed to expand, disseminate and explain the body of knowledge regarding the existing phenomena in the

\footnotetext{
1 Universidade Federal de Pernambuco, Centro de Artes e Comunicação, Departamento de Ciência da Informação. Av. da Arquitetura, s./n., Cidade Universitária, 50740-550, Recife, PE, Brasil. Correspondence to/Correspondênciapara:M.A.A. SILVEIRA.E-mail:<muriloas@gmail.com>.

2 Universidade Federal do Rio Grande do Sul, Departamento de Ciências da Informação, Programa de Pós-Graduação em Comunicação e Informação. Porto Alegre, RS, Brasil.

Received in 1/16/2014, resubmitted on 10/20/2014 and approved in 11/17/2014
} 
world, according to rules and standards of conduct. The plurality of practices expressed to a greater or lesser extent and the dynamics and dimensions of the processes undertaken by the community lead to concrete results of science.

Recognizing that concepts that surround scientific forums enable new ways of knowing and understanding the world through self-criticism, Gramsci (1981) attributes to language and knowledge a relevant role in world views. According to the author, the most important in discovering new truths is to reveal and socialize existing truths that can be

[...] become the basis of vital actions, an element
of harmony and intellectual and moral order. The
fact that a multitude of men are encouraged to
think present reality concretely and unitary is a
far more important and original philosophical fact
(Gramsci, 1981, p.14) ${ }^{3}$.

This concept, which not only values scientific production but the socialization of its results, helps to define the events as one of the exemplary forms for the realization of this ideal.

Scientific practices are spread by institutionalized cognitive and social actions that define, delimit, regulate and legitimize education, development and limits of a field of knowledge (Whitley, 1974; Mueller, 2003). According to Bourdieu (2007), scientific practices are supported by distinctive rituals that result from cultural capital accumulation of practitioners of science by means of different positions and functions adopted throughout their life. Therefore, it is stated that the practices carried out participate in the logic of symbolic exchanges, shaped in power relationships by assigning value and setting standards.

The interest in the study of scientific practices, as part of the scholarly communication system, reflects on the relevance of the debate on topics related to the subject, in order to expand the discussion from the perspective of Information Science. The argument supporting this discussion stems from the existence of an institutionalized system of rewards and satisfaction, the components of ideology that influence power relationships among scientists. To the extent that practices manifest power relationships, it is important to understand their consequences on the economy of symbolic exchanges, as proposed by Bourdieu (2013). It should be pointed out that, from an ideological point of view, the power relationships established in scientific practices intend to maintain the status quo and reinforce the dynamics of social reproduction in science.

Scientific forums are the most diversified instruments of knowledge dissemination because they allow multiple manifestations of communication. Forms of communication covered by most events are oral and/ or written, but the combination of the two are the most recurrent. The two forms together represent different moments of scientific debate among scientists within spatially and temporally limits, favoring the exercise of critique (Ziman, 1979; Meadows, 1999).

Discussions undertaken in events occur before, during and after the discursive level (oral or recorded) occur by means of evaluations, presentations, discussions, suggestions, recommendations, and so on. Thus, it is assumed that events are instances of the reproduction of scientific logic in which power relationships are manifested as a sine qua non condition for the maintenance and perpetuation of the status quo of scientific activity.

In this perspective, the central objective is to discuss theoretically the nature of the main scientific practices and power relationships in events as instances of social reproduction of science. We intend to highlight the ideological propositions that establish the communication processes of science regarding the activities of production and acclaim as elements of the scientific communication system.

The main claim for the discussion is to reflect on the ideological aspects present in the events from a social point of view in the light of theoretical references on the theme. We emphasize the identification of possible manifestations of existing power relationships in the practices of members of the scientific communities and the consequences for the development of science. In this sense, the central point is to understand how to manage disagreements, relationships and discussions that lead to the production and communication of scientific knowledge, in order to point out the practices that represent the process of social reproduction.

\footnotetext{
3 "[...] transformadas em bases de ações vitais, em elemento de coordenação e de ordem intelectual e moral. Ofato de que uma multidão de homens seja estimulada a pensar concretamente e de maneira unitária a realidade presente éum fato filosófico bem mais importante original".
} 


\section{Scientific forums and the scientific communication system}

Scientific forums in the scholarly communication system are considered oral and recorded means for the dissemination of knowledge that assemble members of a scientific community for a face-to-face meeting around a theme. They are organized by entities and institutions involved in scientific or professional practice in a field of knowledge, or specialty, with the aim of promoting debate and socialization of experiences. At the end of the event, a few print runs of the document with the records of the presentations are distributed among the participants (Mello, 1996).

In general, a scientific forum is considered an informal communication resource founded on information sharing on a specific theme for a particular social group (Meadows, 1999; Targino, 2000). Because of its (mostly) regular periodicity, events are proposed as professional development tools to the extent that they promote the interaction among scientists in several ways: lectures, round tables, work presentations, panels, workshops, and mini-courses, among others (Cornish, 1990; Meadows, 1999; Campello, 2003). Meadows (1999) also emphasizes that participants plan making specific contacts during the event and the occurrence of unexpected meetings, which are useful for the development of their work. However, Miyamoto (1987) and Lacerda et al. (2008) note that motivation to participate in events can, in some cases, be more related to the journey itself than the need to exchange of experiences.

Concerning the denomination of the events, Silveira et al. (2006) highlight the following: congresses, conferences, symposia, meetings, forums, among others, according to the scope of the event. According to the website of Universidade Estadual de Campinas (2013, online), the following distinction is pointed out:
Congress: meeting or gathering of professional associates or associations for the presentation of conferences [...]. Seminar: Meeting of a study group to discuss topics proposed by the participants. [...]. Course: set of materials or lessons taught in classes, conferences or lectures. Lecture: talk, presentation of ideas or concepts on a certain topic [...]. Exhibition: public presentation of artistic, industrial, technical or scientific production [...]. Symposium: Meeting of a certain technical, artistic or scientific group to debate a particular subject and topic related their interests. Panel: a meeting restricted to a small number of specialists whose members discuss topics among themselves [...]. Forum: less technical meeting whose goal is to achieve the effective participation of a large audience, who must be motivated. Conference: a public lecture on a particular technical, artistic, scientific or literary subject [...]. Lecture series: similar to conference but related to a series of lectures given by experts in the field addressed. Meeting: a meeting held regularly by professional groups with the purpose of preparing a discussion for a congress ${ }^{4}$.

The above mentioned denominations and so many others in the literature are far from being universal and they do not include the size and scope attributed by social groups to events. Within this perspective, the record is only to define the differences between the concepts in order to establish the proper grounds of the events. Thus, the above definitions and classifications found in the literature are shown in Table 1.

Commonly, the frequency of scientific forums are: (a) large and medium: annual or biannual; (b) small: weekly, fortnightly, monthly or quarterly; and (c) training: monthly, quarterly or annual. It is important to mention, however, that the frequency is usually not a rule, since the nature of the event is determined by the social group responsible for its organization.

On the organization of events, social groups who generally conduct activities are professional and/or

\footnotetext{
${ }^{4}$ Congresso: reunião ou encontro de entidades de classe ou associações para a apresentação de conferências [...]. Seminário: reunião de um grupo de estudos que centraliza debates de assuntos expostos pelos participantes [...]. Curso: conjunto de matérias ou lições ministradas em aulas, conferências ou palestras. Palestra: conversa, apresentação de ideias ou conceitos sobre determinado assunto [...]. Exposição: exibição pública de produção artística, industrial, técnica ou científica [...]. Simpósio: reunião de iniciativa de terminada classe técnica, artística ou científica para debates ligados a um assunto específico e a discussão de tema afim a seus interesses. Painel: reunião limitada a um pequeno número de especialistas, em que os expositores debatem entre si o assunto em pauta [...]. Fórum: reunião menos técnica cujo objetivo é conseguir a efetiva participação de um público numeroso, que deve ser motivado. Conferência: trata-se de uma preleção pública sobre determinado assunto técnico, artístico, científico ou literário [...]. Ciclo de Palestras: derivado da conferência, difere desta pelo fato de poder estar vinculado a uma série de palestras pronunciadas por especialistas na matéria abordada. Jornada: reunião de determinados grupos de profissionais realizada periodicamente, como objetivo de discussão em congressos.
} 
Table 1. Size and denomination of scientific forums.

\begin{tabular}{ll}
\hline Size of forums & Denomination of forums \\
\hline \multirow{2}{*}{ Large } & Congress \\
& Meeting \\
& Seminar \\
& Symposium \\
& Convention \\
Médium & Day meeting \\
& Coloquium \\
& Forum \\
& Conference \\
& Round table \\
Small & Lecture \\
& Panel \\
& Exposition \\
Training & Course \\
& Short course \\
\hline
\end{tabular}

Source: Developed by the authors (2014).

scientific institutions, universities and their administrative departments, public or non-governmental organizations, and other organized and recognized social segments (Meadows, 1999; Campello 2003; Universidade Estadual de Campinas, 2013). The organization consists of parties responsible for the board, subject to an overall management for the implementation of specific actions. The diversity of committees is related to the size and specific characteristics of the event, the most frequent being: scientific, financial, fundraising, infrastructure, cultural, communication board, among others (Universidade Estadual de Campinas, 2013).

Another point to be considered in the organization of events is related to the financial aspects, beginning with expenses in the planning stage up to the preparation of the technical and financial report. The resources usually come from endowments from members of the specific community, or revenue generated through registrations (Campello, 2003). Other fundraising possibilities include: financial grants from funding agencies, public agencies, companies and other institutions interested in the event (Miyamoto, 1987; Universidade Estadual de Campinas, 2013). However, it is worth mentioning that the organizers face difficulties in this regard since in most cases the only source of revenue is registration, while expenses must be met before the event. This situation makes it impossible to plan certain activities before the event, compromising its implementation, as well as other related actions.

Marchiori et al. (2006) report that there are four categories of participants related to the events, namely:

a) members of the scientific committee: responsible for organizing the event;

b) featured guests: participants who are in the official program of the event and received an official invitation from the organization to participate;

c) guests: target audience for whom the event was organized; and

d) presenters of open themes: attendees responsible for oral communications and posters submitted to the scientific committee, in a subject area designed for that purpose.

The authors indicate that the category "featured guests" includes lecturers, speakers, panelists, table moderator, among others. The only problem related to the categories described by the authors is the first category of participants as there are board members of the scientific committee as well as executive committee. In this sense, the suggestion is to suppress the use of the term scientific or suggest another term that includes the various activities among the organizers.

With regard to the function of scientific forums, it can be said that its key role is to promote informal communication among peers. However, many other functions are evident, but not always mentioned. It is believed that this situation reveals no obvious functional aspects, but important and vital to the scholarly communication system, determined by personal and professional interests of scientists. The explicit activities of the scientific forums, according to Ziman (1979), Meadows (1999) and Marchiori et al. (2006), are:

a) to disseminate theoretical and methodological knowledge of the research process to the scientific community;

b) to provide a favorable environment for debate and the exchange of experience and information among scientists; 
c) to serve as an instrument to update and systematize recent theoretical and methodological advances in a field;

d) to establish plans, rules and standards of conduct, short- and medium-term goals and objectives in a scientific field, referring to political, social and epistemological orientation;

e) to maintain cognitive and social files of science updated.

Most events publish documents known as conference proceedings, which are nothing more than documents issued by the team of the event that makes the papers, lectures and other important information available to the community (Mello, 1996; Campello, 2003). It is, therefore, a systematic and formal organization of knowledge with the purpose of recording and document filing. However, in earlier times, event organizers faced great difficulty to publish the proceedings due to obstacles related to cost and editing (Mello, 1996). Currently, these publications are recorded using mechanisms of document control in order to preserve and disseminate knowledge, becoming a chain production of certified information, thanks to the facilities provided by information technology.
Knowledge dissemination practices developed in scientific forums are highlighted by the plurality of the objectives and characteristics. Regarding the objectives, the practices for knowledge dissemination of events can be: (a) communication; (b) update; and (c) maintenance. As for the characteristics, the practical goal of the events is to: (a) disseminate research results; (b) disseminate news; (c) present novelty; $(d)$ acquire and preserve status and; (e) support grant funding. The distinction of scientific practices in events is discussed in the literature, known as structure, and it focuses mostly on aspects of dissemination of knowledge (Campello, 2003; Marchiori et al., 2006). The proposed distinction seeks to broaden the scope of the diversity of practices, based on the understanding that not only dissemination of knowledge contributes to the strengthening of the scholarly communication system. To highlight the multiple possibilities of practices, Table 2 shows the discussion in the literature.

It is worth noting that there may be other practices as well as other goals and characteristics, and this categorization is a suggestion to show the structuring processes of scientific forums.

Table 2. Scientific practices of scientific forums.

\begin{tabular}{|c|c|c|}
\hline Practical goals & Caracteristics of practices & Discrimination of practices \\
\hline Comunication & Disseminate research results & $\begin{array}{l}\text { Oral communication } \\
\text { Poster communication } \\
\text { Lectures } \\
\text { Round tables }\end{array}$ \\
\hline \multirow[t]{2}{*}{ Update } & Disseminate news & $\begin{array}{l}\text { Painels } \\
\text { Lectures } \\
\text { Round tables } \\
\text { Meetings }\end{array}$ \\
\hline & Present novelty & $\begin{array}{l}\text { Workshops } \\
\text { Technical meetings } \\
\text { Courses }\end{array}$ \\
\hline \multirow[b]{2}{*}{ Maintenance } & Acquire and preserve status & $\begin{array}{l}\text { Oral communication } \\
\text { Poster communication } \\
\text { Lectures } \\
\text { Round tables } \\
\text { Technical meetings }\end{array}$ \\
\hline & Support grant funding & $\begin{array}{l}\text { Courses } \\
\text { Technical meetings } \\
\text { Courses }\end{array}$ \\
\hline
\end{tabular}

Source: Developed by the authors (2014). 


\section{Practices of researchers and power relationships in scientific forums}

The premise underlying this section is that scientific practices are conducted for the purpose of social reproduction, based on the logic of instances of science production and distinction. Thus, the power relationship among scientists is emphasized, reflecting on the impact caused by the relationship on the development of scientific activity.

In accordance with Fleury (2009), the practices carried out in the socialization spaces are essential for the establishment of the culture in a social group. In the process of socialization, the different actors and the roles they play in the social space influence and are influenced by creating the necessary elements that promote cultural appropriation at different levels. The existing contexts favor or hinder cultural appropriation whether by aspects of family and school education or social interactions, thus allowing the accumulation of symbolic capital.

The concept of cultural capital analyzed by Fleury (2009) derives from the theoretical discussion developed by Bourdieu $(1999,2007)$ as a result of the institutionalization of social practices by both the individual and the group. In turn, these practices (or habitus) have the function to combine the experiences of the past with the present and the future in order to perpetuate the tastes, styles and preferences of a social group. However, it should be stated that each member will have their own experiences, some of which are shared and cultivated with the other, thus integrating the set of habitus of the social group. Within this context of individual and collective habitus, in which interests and actions converge and diverge in sensitive levels of perspectives, cultural capital is consolidated (Bourdieu, 2007).

Thompson (1995) indicates that all the practices carried out by men are conducted to a greater or lesser extent by a system of ideas organized in mind that conform personal and collective interests, being subjacent to those of society. These conformations - also known as ideologies - seek to be in alignment with the purpose of bringing together interests and social practices so that the individual and society are in harmony with a single purpose. However, the author points out that because of the diversity of practices, individual and collective interests collide, causing conflicting processes among the parties and encouraging the emergence of ideologies.

Due to conflicts, individuals with common interests are organized into groups to foster their practices, establishing, according to Thompson (1995), its ideological components. Organizations of different social segments advance and retreat due to the connection between the members and the relative levels of accumulated cultural capital. In this process, social classes are based on cultural capital, to a greater or lesser extent, establishing the domination schemes, and consequently inequalities of disputes between center and periphery (Thompson, 1995; Bourdieu, 2007). According to Bourdieu (1999; 2007), conflicts between social groups are based on the imposition of values and beliefs socially shared in the midst of socio-cultural changes. As a result there is the crystallization of the actions and attitudes of individuals in society, determining the basis of social representations and promoting mechanisms of social reproduction (Thompson, 2005).

Values and beliefs, according to Bourdieu (2004, 2013), also apply to the scientific universe as the result of the training in scientific fields and their communities. For the author, the definition of the structure of a community is not usually rigid around a specialty, and in specific circumstances it can relate to others through the association or reorganization of common goals. Its demarcation is limited by training institutions, dissemination, professional activity in local, regional, national and international regulation (Bunge, 1980). The performance level of a community towards the other is directly conditioned by the activities carried out by researchers, both individually and collectively. In these terms, it is the scientific community who determines the political, social, cognitive and economic structures of the scientific field, in which all elements become dependent on each other (Whitley, 1980).

Regarding the scientific field and researchers, Bourdieu $(1983,2004)$ points out that the actors, institutions and events are crucial for scientific activity; as a result, actions and products that show competition, cooperation, conflicts and inequalities, which result in the legitimization of actors, fields and practices, in addition to establishing a scientific culture based on trade 
relationships (Bourdieu, 1999). In the course of the interactions among the practitioners of science, power relationships are unequal among researchers because the instances of dedication that perpetuate an order of social reproduction, creating explicit or implicit areas of stress that increase inequalities (Bourdieu, 1999; Bourdieu \& Passeron, 2008).

After initial considerations on the relative strengths among social groups due to accumulated intellectual capital, the discussion arouses the diversity of scientific practices developed by scientists in the events. Given the plurality of scientific practices carried out in events, our study will be limited to the acts and discourses of scientists in the light of the references of Goffman (2005). According to the author, the social life of an individual has different social roles depending on the conveniences determined by specific contexts. This representation is motivated by the aspirations of the individuals, allowing them to "embody" distinct roles to make their everyday life a spectacle.

Considering the actions and discourses of scientists in scientific events, the resources used to represent their role are:

a) physical: gestures, body positions;

b) sentimental: impressions, deductions, affections;

c) discourse: speech, text, performance;

d) scenic: clothing, accessories, objects;

e) instrumental: artifacts related to human activity.

It should be noted that the previously mentioned characteristics can be activated simultaneously, but they also allow the existence of other characteristics. To demonstrate the power relationship that govern social reproduction in science, our study classifies scientists as experienced, transient and beginners, in that order, in a decreasing level of scientific experience.

The lectures and round tables in events are practices of scientific dissemination that spread ideas, concepts, information and news in general, and are delivered by experts on a subject, focusing on aspects related to the theme of the event or interests of community. They are organized alone or together in a specific session (round table) and moderated by renowned people (Marchiori et al., 2006; Lacerda et al., 2008).

In these scientific practices, the lecturers tend to express their knowledge orally and/or by means of texts written to meet the theme of the event. The expert may use a theatrical performance (physical and scenic resources) in order to secure the public's attention and refer to events and situations related to the context of the lecture. Other resources can also be used to increase the expectation of listeners, but when these are not well employed, the lecture might become unsuccessful.

Another possibility of spreading knowledge during events refers to open communications of oral or poster presentations of participants who have undergone a preliminary evaluation before the event that refer to the knowledge produced and/or the related to professional experience. These scientific practices are moderated by coordinators and organized into thematic sessions in order to establish dialogue and promote discussion among the attendees (Meadows, 1999; Marchiori et al., 2006).

In the case of open communications, the participants, experienced, transient and beginners, expose and are exposed to a discursive interaction in which the arguments are confronted, in an atmosphere of "epistemological vigilance" Bourdieu et al. (1990, p.32) to implement the principles of applied rationalism that takes into account "not only the application of the method, but the method itself" 6 as a scientific requirement and a resource for self-control and epistemological safeguard to prevent the contamination of pre-notions. The interaction is driven by physical, emotional and discursive resources by means of discussing the contents presented, but they are supported by other underlying issues in multiple social directions. Beginners are challenged by those who have more experience and their conduct and scientific activity is tested. The primary experience of some is transformed into scientific practice and changes it, according to Bourdieu (2003). The experienced and transient seek to maintain the relevance of their ideas and theories, often

\footnotetext{
5 "vigilância epistemológica".

6 "não apenas a aplicação do método, mas o próprio método".
} 
supported by their professional career. In the course of the interactions among participants, dialogues are established, agreements are signed, and differences are fought out, seeking to delimit space, primacy of action, and partnerships.

The set of practices that seek to disseminate news and information of a field or specialty focuses on the supplementation of practices and knowledge dissemination. The function of these practices is almost always to present topics of a political, social, professional and epistemological nature that affect reality and the context of research and researchers in a field of knowledge, particularly those related to the scientific practice (Miyamoto, 1987). The practices with those goals are, commonly, called panels, technical meetings, work groups, among others, complementing the general program of the event under the responsibility of leaders connected to associations, professional councils, or a specific group of researchers.

The purpose of updating researchers by means of news places the panels and technical meetings as practices that privilege the experienced, excluding the transient and beginners. However, some of these practices tend to allow the participation of transient and beginners if granted permission of organizers and researchers.

Due to its small size, panels consist of the exposure of a subject of interest to the community during which the participants discuss and opine on the topic. At this level of interaction among participants, discursive, sentimental and instrumental resources work together in a performance in an endeavor to state accumulated knowledge and presentation of news, events and situations in discussion to assure primacy of dissemination and political and social articulation in the scientific field.

In technical meetings, the audience is larger and the interactions among researchers are aimed at deboting the different contexts that affect research activities and the activities of the researchers. The focus of the discussion privilege the organizers, experts, experienced and researchers who, because of their social position in the field, hold important information that affects the dynamics of knowledge construction. Transients and beginners find little opportunity to state their ideas, avoiding social confrontation with the experienced, establishing their conditions and perpetuating the logic of social reproduction. When performing their roles during these practices researchers use all these resources wrapped in a "theatrical performance" that implies the level of accumulated intellectual capital, both individually and collectively.

The purpose of courses and workshops is to broaden practical and theoretical knowledge and disseminate news that affects the research activities of researchers. The main role of these practices is to update the accumulated body of knowledge by means of presentations and discussions moderated by experienced researchers, members of academic and scientific institutions or by those who are in a privileged position in institutions connected to the field. Meadows (1999) states that courses and other practices are within the boundary between consolidated and new knowledge because they are means for scientific communication that promote the dissemination of news and information related to the field as continuing training for the community members. These practices, therefore, carried out by specialists with a didactic and pedagogical goal to transfer theoretical and applied knowledge that influence the activities of many researchers in the field. Event organizers charge registration fees and other fees to cover the cost of materials, to pay experts and other parties, to preserve and maintain equipment, in addition to being a tool for fund collection for institutions promoting the event and other activities that occur after the events.

Interactions in accordance with these practices of continuing education reinforce the existence of hierarchy in science to the extent that the social outline of the field establishes the positions occupied among experienced, transient and beginner researchers: the first are the educators, while the transient and beginners are being trained. When sharing knowledge scientific rigor is expected from experienced researchers as well as availability and interest to discuss. In turn, transient and beginners seek to update their theoretical and methodological knowledge and to advance their participation in discussions in order to put themselves in social evidence, being in accordance with the accumulated scientific capital. At the core of the theatrical spectacle seen during courses and workshops, the physical, discursive and instrumental resources are used more frequently because they allow the objectification of representation of those involved and when necessary, 
supplemented by sentimental and scenic resources. It is worth mentioning that the training practices place all researchers in a social scale of the field, qualifying starters, validating the transient and acclaiming the experienced through consensus.

As previously discussed, power relationships among community members in events may occur in different ways, and in many cases it cannot be perceived during the practices. The relationship of forces is not equal among researchers because instances of distinction through intellectual (cultural) capital accumulated establish an order of social reproduction. Within the set of scientific practices found in events, social groups are formed, disputes are established and areas of stress are created, explicitly or implicitly, that extend inequalities and reinforce ideologies. To overcome the differences between the interests amid the integrated set of habitus and ideological components, social segments come to an understanding for the full development of science.

Given the lack of synchronicity between the market of symbolic goods and this reality, the scientific capital becomes leverage as the individual attains a position in the hierarchy of scientific values through it. In this regard, Bourdieu (2013, p.43) recognizes that "for each science, a complex and contentious hierarchy of reviews and publishers, of foreign countries and colloquia and also that those who refuse to participate may appear difficult to distinguish from those who are not invited." The commercial process related to scientific practices results in a hierarchical society based on the success or failure of individuals or groups, determined by cultural capital. The interpellation among subjects to strengthen positions, areas of expertise, and future partnerships and agreements leads to the development of accumulation, strength and increase of benefits of the segments and more established social groups.

\section{References}

Bourdieu, P. O campo científico. In: Ortiz, R. (Org.). Pierre Bourdieu. São Paulo: Ática, 1983. p.122-155.

Bourdieu, P. A distinção: crítica social do julgamento. São Paulo: EdUSP, 2007.

Bourdieu, P. A economia das trocas simbólicas. São Paulo: Perspectiva, 1999.

Bourdieu, P. Homo academicus. 2.ed. Florianópolis:UFSC, 2013.

\section{Conclusion}

The reflection held on the nature and main characteristics of scientific events deserves further discussion of some situational aspects as scientific practices have undergone significant changes due to the increasing tendency to value this type of activity and measure symbolic profits in the field of scientific production. The incursion of the spirit of the market of symbolic goods is done through various instruments, including scientific events, which is why the studies on its process are expressions of social surveillance.

The possibility of critical analysis of scientific events will be always attributed to value attribution of these events. This criticism, in turn, can be guided on the one hand by the inclusion of events such as market products inserted as a process of cultural reproduction and, second, their potential as moderator elements in the production, review and improvement of knowledge.

Our reflections indicate scientific questions about the imbalances of power among researchers when performing social practices in science. The choice of events as a means for science communication was due to the plurality of the contemplated practices, as well as the possibilities of manifestation of ideologies between top and bottom. In this context, it was found that the universe of scientific activity accompanies the logic of social reproduction seen in other contexts. Events are a privileged locus to the extent that the actors and the roles played accentuate the clash between individuals.

In the present study we sought to understand the aspects that guide the actions taken by the scientific communities. We suggest further theoretical discussions in the light of other references and even the observation of other instances and circumstances to the extent that they can further the interests of Information Science.
Bourdieu, P. Participant objectivation. Journal of the Royal Anthropological Institute, v.9, n.2, p.281-294, 2003.

Bourdieu, P. Os usos sociais da ciência: por uma sociologia clínica do campo científico. São Paulo: Unesp, 2004.

Bourdieu, P.; Chamboredon, J.C.; Passeron, J.C. A profissão de sociólogo: preliminares epistemológicas. Petrópolis: Vozes, 1990. 
Bourdieu, P.; Passeron, J.C. A reprodução: elementos para uma teoria do sistema de ensino. Petrópolis: Vozes, 2008.

Bunge, M. Ciência e desenvolvimento. Belo Horizonte: Itatiaia, 1980. (O Homem e a Ciência, v.11).

Campello, B.S. Encontros científicos. In: Campello, B.S.; Cendón, B.V.; Kremer, J.M. (Org.). Fontes de informação para pesquisadores e profissionais. Belo Horizonte: UFMG, 2003. p.55-71.

Cornish, G.P. Non-print conference proceedings: Problems for speakers, librarians and users. Audiovisual Librarian, v.16, n.1, p.18-23, 1990.

Fleury, L. Sociologia da cultura: e das práticas culturais. São Paulo: Senac, 2009.

Goffman, E. A representação do eu na vida cotidiana. 13.ed. Petrópolis: Vozes, 2005. (Antropologia, 8).

Gramsci, A. A concepção dialética da história. 4.ed. Rio de Janeiro: Civilização Brasileira, 1981.

Lacerda, A.L. et al. A importância dos eventos científicos na formação acadêmica: estudantes de Biblioteconomia. Revista $A C B$, v.13, n.1, p.130-144, 2008.

Marchiori, P.Z. et al. Fatores motivacionais da comunidade científica para publicação e divulgação de sua produção em revistas científicas. In: Seminário Nacional de Bibliotecas Universitárias, 14., 2006, Salvador. Anais eletrônicos... Salvador: CBBU, 2006.

Meadows, A.J. A comunicação científica. Brasília: Briquet de Lemos, 1999.

Mello, L.L.C.C. Os anais de encontros científicos como fonte de informação: relato de pesquisa. Revista de Biblioteconomia de Brasília, v.20, n.1, p.53-68, 1996.
Miyamoto, M. Administração de congressos científicos etécnicos: assembléia, convenção, painel e outros. São Paulo: Pioneira, 1987.

Mueller, S.P.M. A ciência, o sistema de comunicação científica e a literatura científica. In: Campello, B.S.; Cendón, B.V.; Kremer, J.M. (Org.). Fontes de informação para pesquisadores e profissionais. Belo Horizonte: UFMG, 2003. p.21-34.

Silveira, M.A.A.; Pereira, C.A.; Oliveira, M.J. As tendências temáticas do SNBU: análise dos anais de 2002 e 2004. In: Seminário Nacional de Bibliotecas Universitárias, 14., 2006, Salvador. Anais eletrônicos... Salvador: CBBU, 2006. 1 CD-Rom.

Targino, M.G. Comunicação científica: uma revisão de seus elementos básicos. Informação \& Sociedade: Estudos, v.10, n.2, p.1-27, 2000.

Thompson, J.B. Ideologia e cultura moderna: teoria social crítica na era dos meios de comunicação de massa. Petrópolis: Vozes, 1995.

Universidade Estadual de Campinas. Eventos e normas. 2013. Disponível em: <http://www.reitoria.unicamp.br/manual deeventos/eventos/proto-eventos_cientificos.shtml>. Acesso em: 8 ago. 2013.

Whitley, R. Cognitive and social institucionalization of scientific specialities and research areas. In: Whitley, R. (Ed.). Social processes of scientific development. London: Routledge and Kegan, 1974. p.69-95.

Whitley, R. The context of scientific investigation. In: Knorr, K.D.; Krohn, R.; Whitley, R. The social process of scientific investigation. London: D. Reidel, 1980. p.297-321.

Ziman, J. Conhecimento público. Belo Horizonte: Itatiaia, 1979. (O Homem e a Ciência, v.8). 
